\title{
Melanoma Antigen Recognized by T-Cells
}

1

National Cancer Institute

\section{Source}

National Cancer Institute. Melanoma Antigen Recognized by T-Cells 1. NCI Thesaurus.

Code C33992.

Melanoma antigen recognized by T-cells 1 (118 aa, $\sim 13 \mathrm{kDa}$ ) is encoded by the human MLANA gene. This protein may play a role in melanin production. 